\title{
DE
}

DE GRUYTER

OPEN

Arch. Min. Sci. 62 (2017), 3, 579-596

Electronic version (in color) of this paper is available: http://mining.archives.pl

DOI 10.1515/amsc-2017-0042

STANISŁAW GUMULA**, WIKTOR HUDY**,

MALGORZATA PIASKOWSKA-SILARSKA**, KRZYSZTOF PYTEL***

\section{ISSUES OF EXPLOITATION OF INDUCTION MOTORS IN THE COURSE OF UNDERGROUND MINING OPERATIONS}

\author{
PROBLEMY EKSPLOATACJI SILNIKÓW INDUKCYJNYCH W WARUNKACH \\ GÓRNICTWA PODZIEMNEGO
}

\begin{abstract}
Mining industry is one of the most important customers of electric motors. The most commonly used in the contemporary mining industry is alternating current machines used for processing electrical energy into mechanical energy. The operating problems and the influence of qualitative interference acting on the inputs of individual regulators to field-oriented system in the course of underground mining operations has been presented in the publication. The object of controlling the speed is a slip-ring induction motor. Settings of regulators were calculated using an evolutionary algorithm. Examination of system dynamics was performed by a computer with the use of the MATLAB / Simulink software. According to analyzes, large distortion of input signals of regulators adversely affects the rotational speed that pursued by the control system, which may cause a large vibration of the whole system and, consequently, its much faster destruction. Designed system is characterized by a significantly better resistance to interference. The system is stable with the properly selected settings of regulators, which is particularly important during the operation of machinery used in underground mining.
\end{abstract}

Keywords: mining machinery, electric motors, control, efficiency indicators

Branża górnicza jest jednym z ważniejszych odbiorców silników elektrycznych. Najpowszechniej stosowane w branży górniczej są obecnie maszyny prądu przemiennego służące do przetwarzania energii elektrycznej w energię mechaniczną. W artykule przedstawiono problemy eksploatacji i wpływ jakościowy zakłóceń działających na sygnały wejściowe poszczególnych regulatorów w układzie polowo-zorientowanym w warunkach górnictwa podziemnego. Obiektem sterowania prędkością obrotową jest silnik indukcyjny pierścieniowy. Nastawy regulatorów obliczono przy zastosowaniu algorytmu ewolucyjnego. Badanie dynamiki układu przeprowadzono metodą komputerową korzystając z oprogramowania MATLAB/

* AGH UNIVERSITY OF SCIENCE AND TECHNOLOGY, FACULTY OF ENERGY AND FUELS (KMCP), AL. A. MICKIEWICZA 30, 30-059 KRAKOW, POLAND

** PEDAGOGICAL UNIVERSITY OF KRAKOW, INSTITUTE OF TECHNOLOGY, 2 PODCHORĄŻYCH STR., 30-084 KRAKOW, POLAND

*** AGH UNIVERSITY OF SCIENCE AND TECHNOLOGY, FACULTY OF MECHANICAL ENGINEERING AND ROBOTICS (KSEIUOŚ), AL. A. MICKIEWICZA 30, 30-059 KRAKOW, POLAND

\# Corresponding author: stangum@gmail.com 


\begin{abstract}
Simulink. Jak wynika z analiz, duże zakłócenie sygnałów wejściowych regulatorów niekorzystnie wpływa na przebieg prędkości obrotowej realizowanej przez układ sterowania, co może spowodować wystąpienie dużych drgań całego układu, a w konsekwencji jego znacznie szybsze zużycie. Przy odpowiednio dobranych nastawach regulatorów zaprojektowany układ charakteryzuje się większą odpornością na zakłócenia i jest przy tym stabilny, co jest szczególnie istotne w trakcie eksploatacji urządzeń wykorzystywanych w górnictwie podziemnym.
\end{abstract}

Słowa kluczowe: maszyny górnicze, silniki elektryczne, sterowanie, wskaźniki efektywności

\title{
1. Introduction
}

The need for efficient use of energy imposes requirements of EU and Polish law on the companies. Mining industry is one of the recipients of electric motors. The most commonly applied electric motors used in the mining industry are alternating current equipment, which are used to convert the electrical energy into mechanical energy. Mining machinery for coal exploitation and processing, machinery for mining and equipment for mineral raw materials, generally represent the industry in which development and manufacturing experience plays a considerable role (Pytel \& Jaracz, 2012; Gumula et al., 2014a). Both longwall systems and shearers, roadheader, scraper and belts conveyors, powered roof supports, underground haulage and transport equipment, electrical appliances as well as hydraulic components must be adapted to work in the toughest operating conditions. Simultaneously they must be equipped with elements to protect the staff and the machine. Thus, on a par with the requirements of safe operation of mining machinery and equipment, the continuous improvement of construction and introduction of new technologies is of major importance (Pytel \& Jaracz, 2012; Gumula et al., 2014b).

Nearly $90 \%$ of the total sales of electric motors in the European Union are three-phase induction motors. The universality of their applications makes this group of equipment as consuming the largest share of energy produced in power stations (up to $60 \%$ of the electricity consumed in the domestic economy). Many factors related to a design process of an engine, an efficiency of partial elements of a system, an applied practices for an operation and maintenance are necessary to make up on the field of an energy efficiency of whole drive systems.

The volume of electricity consumed by drive systems is affected by the correct selection of an engine in terms of electrical and mechanical parameters, by the quality of the power supply, by a mechanical transmission system, by a maintenance, by motor and end-use device efficiency and by speed control methods.

The electric motors process electrical energy taken from the electricity network into mechanical energy occurring on the motor shaft. In this process, part of the absorbed energy is dispersed in the form of dissipated heat due to losses in the engine. The efficiency of the engine is the parameter determining the amount of losses in relation to processed power (OrłowskaKowalska, 2003).

In spite of the fact that the induction motor efficiency is high and a large number of machines is installed, therefore the improvement of engine operating parameters, improvement in the quality of the materials used, improvement in manufacturing processes are becoming important tasks in terms of ecological and economic improvement (Leonard, 1985).

Safety, efficiency, resistance to overloading and operating risks, resistance to environmental conditions and noise emitted are essential for exploitation of the engine operating parameters. Optimized modern electric drives, which make use of the available technical and economic potential and feasibility, are the optimal electric drives characterized by, inter alia, the ability to 
set and control the starting torque and torque under load, the possibilities of speed regulation in a wide range, the ability to reliable supplies of energy to the system, reduction of losses, processes automation at start-up regulation of rotational speeds, and braking.

The methods of vector control: direct torque control (DTC) and field-control-oriented (FOC) are used in modern drive systems. There are more controls than direct torque control system in the field-oriented system resulting in number of difficulties in parametric optimization of the system (Hudy \& Noga, 2014).

Field oriented control systems could be indirect field oriented control (IFOC) and direct field oriented control systems (DFOC). The DFOC systems might have a different number of regulators and a different type of regulators. The DFOC system was adopted with five PI regulators for further consideration. The analyzed system is consisted with two current regulators, a speed regulator, a flux regulator, and an electromagnetic torque regulator (Fig. 1), that is:

$\mathrm{M} \quad-$ slip-ring induction motor;

F $\quad-$ the inverter;

PI $\quad-$ PI type linear regulators;

$\omega_{s} \quad-$ set point speed controlled induction motor;

$U_{d} \quad-$ reference voltage of the inverter F;

OS $\quad-$ modulus of electromagnetic flux weakening;

$u, i \quad-$ voltage and current phase induction motor;

$\omega \quad-$ current value of induction motor's rotational speed;

$\cos \gamma_{s}, \sin \gamma_{s}-\operatorname{cosine}$ and sine of the angle needed for the transformation of the xy to the $\mathrm{ABC}$;

$m_{e} \quad-$ the estimated value of the electromagnetic torque motor;

$\Psi_{s} \quad-$ the estimated value of the motor magnetic flux;

$T \quad-$ tachogenerator - measuring the speed of an induction motor.

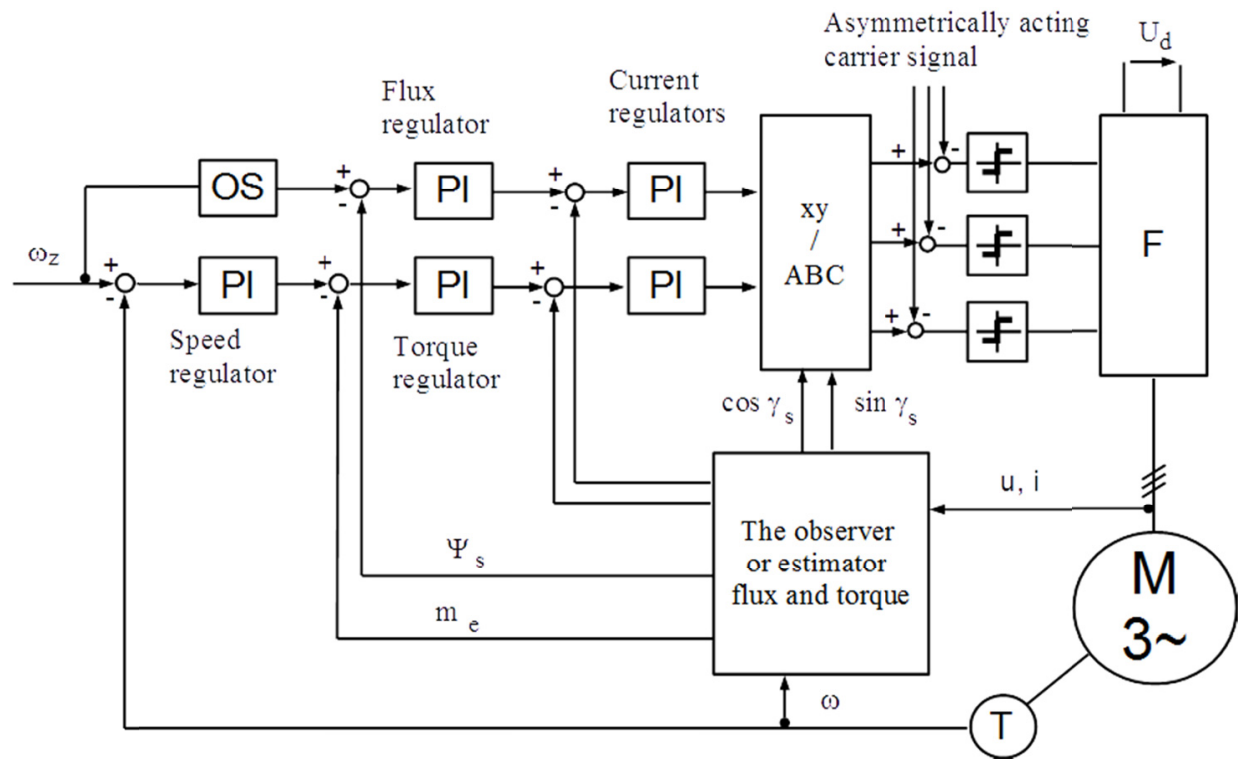

Fig. 1. Examined control system 
Used during the analysis the PI type linear regulators were labelled with the following designations:

PI1 - current regulator in the signal path of the flux regulator;

PI2 - current regulator in the signal path of the speed regulator;

PI3 - flux regulator;

PI4 - torque regulator;

PI5 - speed regulator.

Analyzed system is characterized by the angle of $\gamma_{s}$, which value should be known to transformation during calculations and it is calculated based on current and faze voltage measurement and on the basis on mathematical model of induction motor (mathematical model of induction motor parameters, which is earlier identified with evolutionary methods control object (Hudy, 2013).

Results of analysis, which serves the parametric optimization process, were done by use of numerical method with the help of evolutionary algorithms. Evolutionary programs were written on the basis on mathematical model of prepared control system.

\section{Additive sinusoidal type interference}

A tested control system to field-oriented is a system which comprises 5 PI controllers. Each of these regulators is characterized by two parameters: the strengthening of the regulator and the integral time. In the process of parametric optimization of the control system, ten parameters would be calculated. These parameters were calculated by the evolutionary algorithm in the audited control system. Evolutionary algorithm is an algorithm that uses random numbers. Each time it runs, it causes slightly different values of calculation. It is assumed that the results obtained using evolutionary algorithms differ from the results of the optimal by no more than $5 \%$.

The applied evolutionary algorithm (Fig. 2) is characterized by a number of features:

- it works in parallel on a group of solutions, called individuals;

- each individual is a complete vector of the 10 elements with the values of the parameters of regulators;

- each individual is attributed to the value of the fitness function, which is calculated as the difference between the time characteristic: predetermined that had to realize the control system and the real time characteristic generated on the basis of the vector often elements;

- the value of the evaluation function was calculated as the sum of the modules of differences between time characteristics at each point of a simulation $\left(t_{s}=5 \mathrm{~s} ; \Delta t=0.001 \mathrm{~s}\right)$;

- the time characteristic of rotational speed (Fig. 3a) and step change load torque reference value (Fig. 3b) are the reference time characteristic;

- the smaller the value of the fitness function is, the individual parameter values are further calculated,

- the objective of the algorithm is to minimize the quality of index.

The algorithm, after being launched, generates a random group of individuals - randomly generates the value of the ten parameters for each individual. In the next step, the algorithm calculates the values of an evaluation function. It begins a main loop of the application. Every cycle of the loop is called a generation. Additional individuals are attached to the main group through the evolutionary operators of the population in each generation. These additional individuals are 


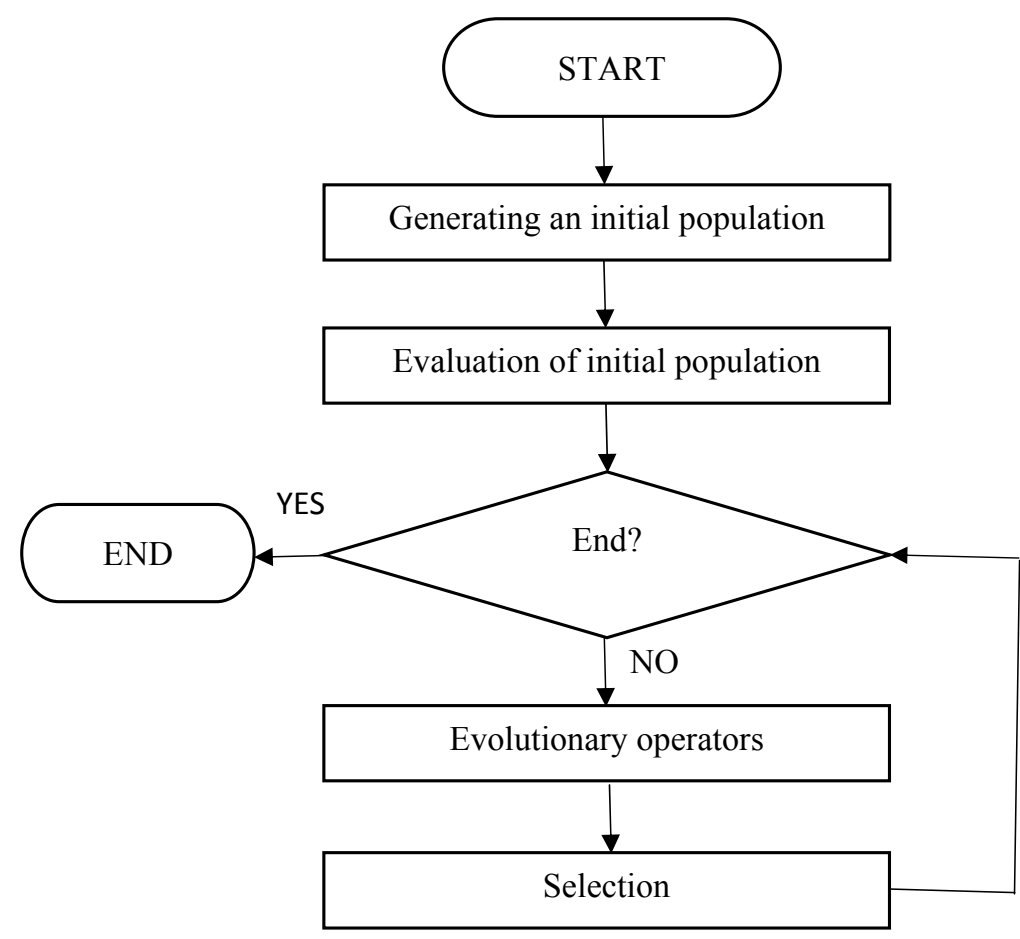

Fig. 2. The applied evolutionary algorithm

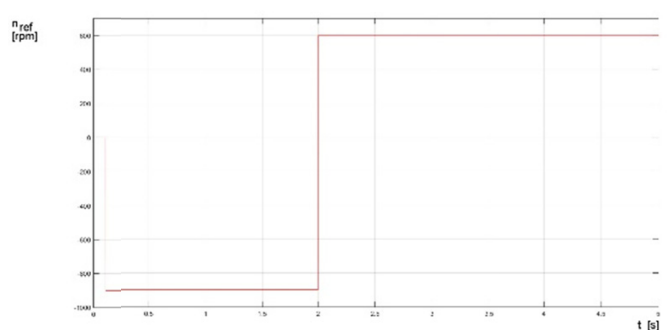

a)

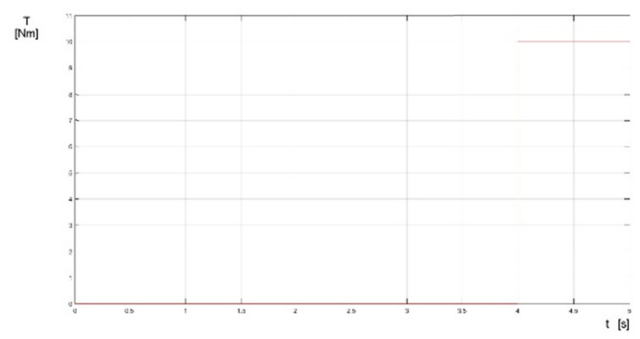

b)

Fig. 3. Time characteristic: a - time characteristic of rotational speed $n_{\text {ref }}$; $\mathrm{b}$ - time characteristic of load torque $T$

calculated on the basis of randomly selected individuals from the main group. They use crossover operators, mutations, progressive mutation. In the next step of the program, additional individuals are evaluated, i.e. values of quality of index are assigned to them. Individuals (with number of input population) are selected to a new population by the selection operator from enlarged group of individuals on the basis of the quality of index, afterward the cycle starts from the beginning. The application checks the termination condition before each loop and continues to operate until a number of cycles reaches the value, which was set up in advance. After completing the program, the population is being viewed for individual with the lowest fitness function. The individual is 
the outcome of the application and represents the control parameters of the tested control system. The aim of this study is to investigate the resistance of the control system with the evolutionary parameters calculated to interference of internal signals of the system.

TABLE 1

Values of MAPE indicator for interfering signals

\begin{tabular}{|c|c|}
\hline \hline No. & MAPE $_{\mathbf{I N}}[\mathbf{\%}]$ \\
\hline 1. & 0 (the reference value) $^{\circ}$ \\
2. & $1 \%$ \\
3. & $2 \%$ \\
$\ldots$ & $\ldots$ \\
51. & $50 \%$ \\
52. & $52 \%$ \\
$\ldots$ & $\ldots$ \\
76. & $100 \%$ \\
77. & $105 \%$ \\
$\ldots$ & $\ldots$ \\
96. & $200 \%$ \\
\hline
\end{tabular}

The mean absolute percentage error was used to determine the degree of interference signals. It is determined by the generally known formula:

$$
M A P E=\frac{1}{n}\left(\sum_{i=1}^{n}\left|\frac{z_{R L V, i}-z_{i}}{z_{R L V, i}}\right|\right) 100 \%
$$

where:

MAPE — mean absolute percentage error;

$n-$ number of points of time in which the calculated quality of index was $(n=5000)$;

$z_{R L V, i}$ - the $i$-th value of the reference time characteristic;

$z_{i}$ - the $i$-th value of the reference time characteristic for which the MAPE index was calculated;

All studies were performed for MAPE index values interfering signals (Tab. 1).

In the case of absence of additive disturbances acting on the inputs of the regulators ( $M A$ $P E_{I N}=0 \%$ ) value of this indicator of the output signal is different from zero. This is due to the method of counting $M A P E_{O U T}$ rate. It was calculated the difference between the reference time characteristic (Fig. 4) and output time characteristic. The case, in which no additive interference included, does not coincide with the given time characteristic. Value of the index without interference equals to $M A P E_{O U T}=6.47 \%$.

\section{The experimental data}

The study was conducted by introducing additive interference signals to input signals of PI controllers (Fig. 5). PI controller model with the introduced interfering signals figure consists of:

- $U_{I N}$ - input signal of PI regulator,

- $U_{\text {OUT }}$ - output signal of PI regulator, 
- $K_{p}$ - proportional gain of PI regulator,

- $T_{p}$ - coefficient dependent on integral time of PI regulator $T_{p}=f(T I)$,

$-1 / s-$ operation of integration.

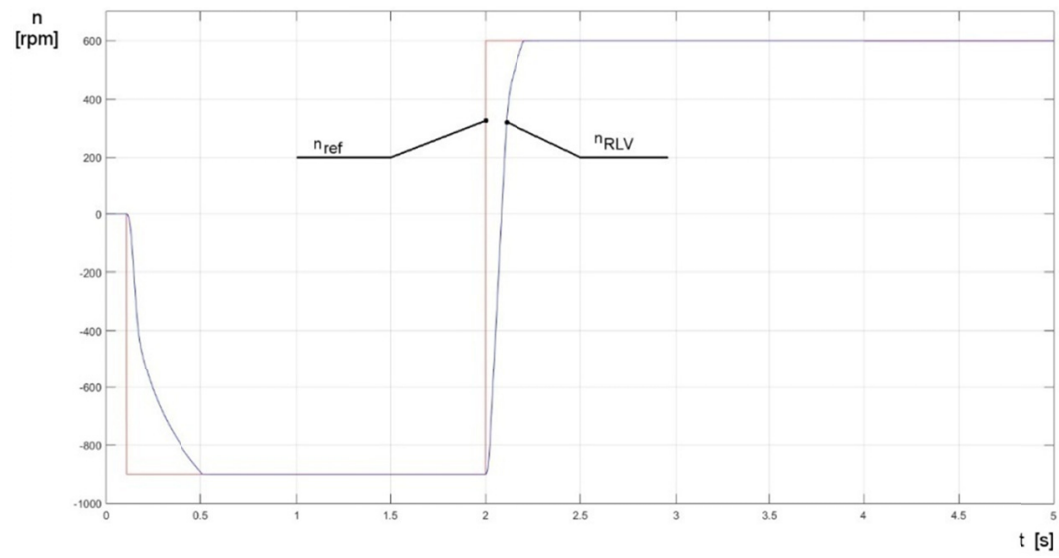

Fig. 4. Reference time characteristic of control system $n_{r e f}$ and real without interference $n_{R L V}$

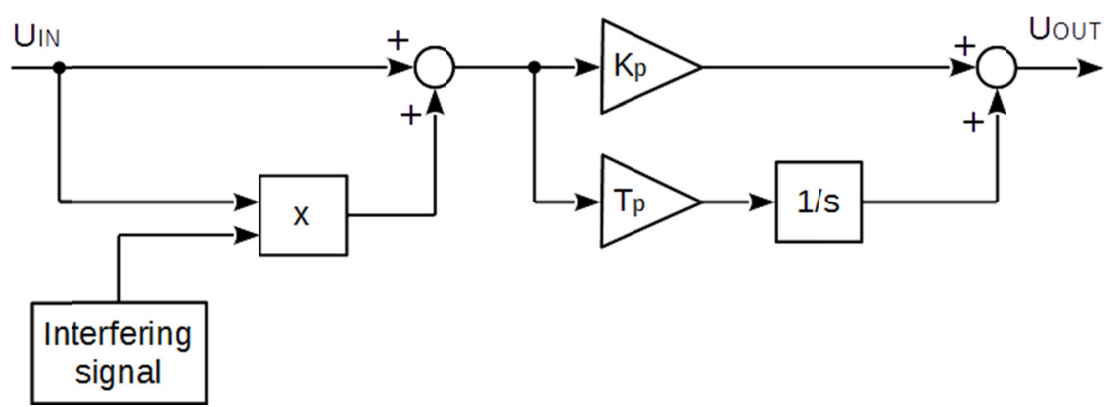

Fig. 5. PI controller model with the introduced interfering signals

The study was conducted by selecting the input signal of the PI controller, multiplying by the interference signal and adding it to the input signal. Then the input signal of the regulator of known type and amplitude of the interference signal were obtained. Additive signals are introduced as follows:

- random number - random numbers in the range of [0,1],

- uniform random number - random numbers in the range of $[-1,1]$,

- chirpsignal - a sinusoidal signal of variable frequency; lower frequency of this signal is set to $0.1 \mathrm{~Hz}$, the upper frequency is set to one of three, i.e. $10 \mathrm{~Hz}, 100 \mathrm{~Hz}$, or $1 \mathrm{kHz}$; change in frequency followed linearly for a period of 0 to 5 seconds (until the end of simulation),

- sine wave - sinusoidal signal of known amplitude and frequency; the frequency range was set at the values (Tab. 1). 
The amplitudes of the additive interference signals are determined as $0 \%$ to $200 \%$ of content of additive interfering signals in the input signal of the PI controller (Tab. 1). The analysis were performed for a variety of interfering signals and for a variety of points of entry an interfering signals.

\subsection{The impact of the additive random number signal on the quality of the regulation}

The influence of an additive random number interfering signal on the input signals of individual controllers separately and all together has been studied. Researches on the influence of interfering additive signal entered on the input of the current controller in the track of the magnetic flux were made.

The impacts of additive interfering signal introduced at the input of the current controller in the track of the magnetic flux were analyzed (Fig. 6 and 7). The value of the reference signal $R_{L V}$, which the value of the index $M A P E_{O U T}$ is equal to $M A P E_{O U T}=6.47 \%$, corresponds to the ideal case without interference introduced.

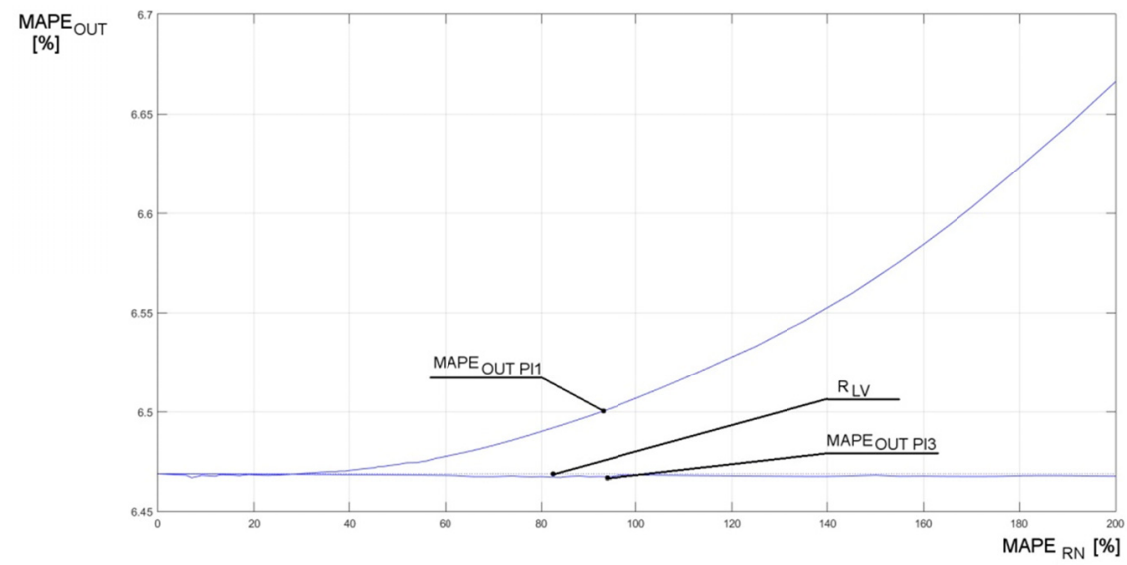

Fig. 6. Characteristics of the output indicator $M A P E_{O U T \mathrm{PI}}$ and $M A P E_{O U T \mathrm{PI} 3}$ according to $M A P E_{R N}$ index value for the random number signal placed on the current input of regulator in the track of the magnetic flux

An impact of additive interference signal (Fig. 6 and 7) is smaller if there are disturbances in the track of magnetic flux regulator. In addition, value of the index MAPE $E_{\text {OUT PI } 3}$ is smaller than the reference level $R_{L V}$. This is due to non-optimal controller settings of the stream. Sub-optimal settings stem from the method of optimization. $M A P E_{O U T}$ index values for regulators in the track of the speed controller grow much faster and are resemble each other.

The value of the interference in the output signal increases with increasing content of additive interference in the input signals of controls (Fig. 8). The content of interference in the output signal is low until the value at $M A P E_{R N}<40 \%$. The increase in additive signal random number above the $40 \%$ in input signals dramatically increases the content of interference in the output signal. 


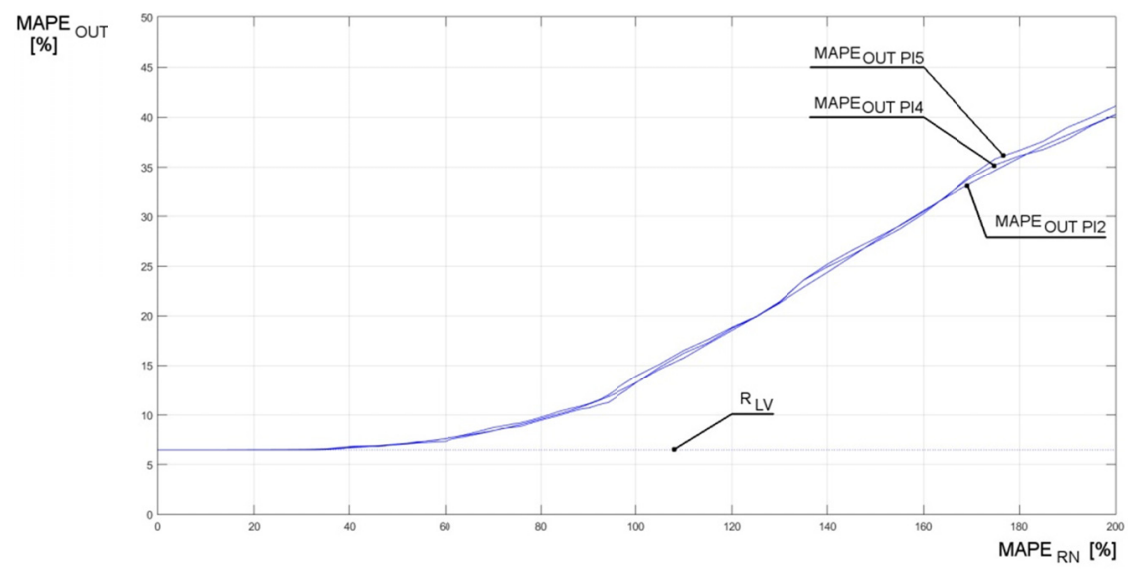

Fig. 7. Characteristics of the output indicators: MAPE $E_{\text {OUT PI2 }}, M A P E_{\text {OUT PI4 }}$ and MAPE $E_{\text {OUT PI5 }}$ according to $M A P E_{R N}$ index value for the random number signal placed on the current input of regulator in the track of the speed and torque

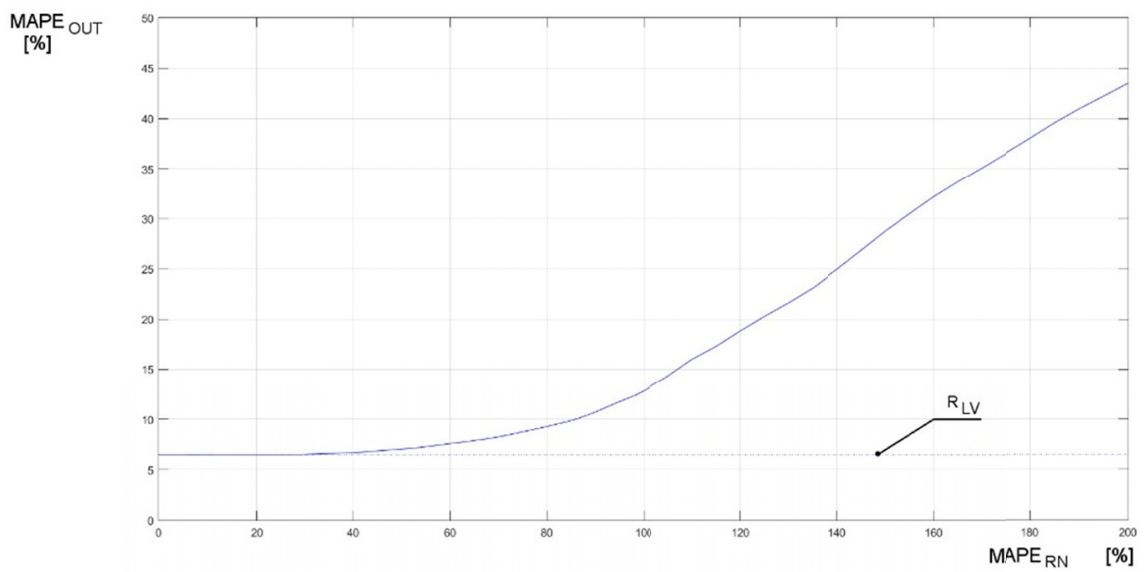

Fig. 8. Characteristics of the output indicators: $M A P E_{O U T}$ for the case, when introduced additive interfering with the input signals of all controllers

\subsection{The influence of additive uniform random number signals on the quality of the regulation}

The influence of an additive uniform random number interfering signal on the input signals of individual controllers separately and all together have been studied. Researches on the influence of interfering additive signal entered on the input of the current controller in the track of the magnetic flux were made.

The impacts of additive interfering signal introduced at the input of the current controller in the track of the magnetic flux were analyzed (Fig. 9 and 10). The value of the reference signal $R_{L V}$, 
which the value of the index $M A P E_{O U T}$ is equal to $M A P E_{O U T}=6.47 \%$, corresponds to the ideal case without interference introduced.

As in the previous case, the effect of additive interference introduced into the input signals of regulators PI1 and PI3 is smaller than the input signals of regulators PI2, PI4, PI5 (Fig. 9 and 10). One input signal is slightly reduced $\left(M A P E_{O U T \mathrm{PI}}\right)$, this is related to the method of optimization.

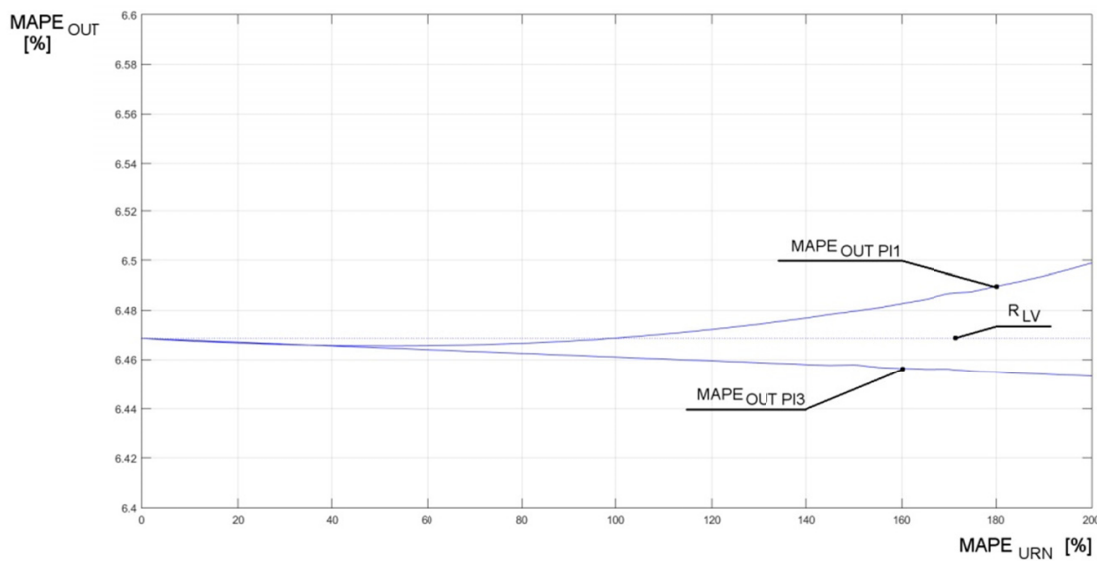

Fig. 9. Characteristics of the output indicators: $M A P E_{\text {OUT PI1 }}$ and $M A P E_{O U T \text { PI3 }}$ according to $M A P E_{U R N}$ index value for the uniform random number signal placed on the current input of regulator in the track of the magnetic flux

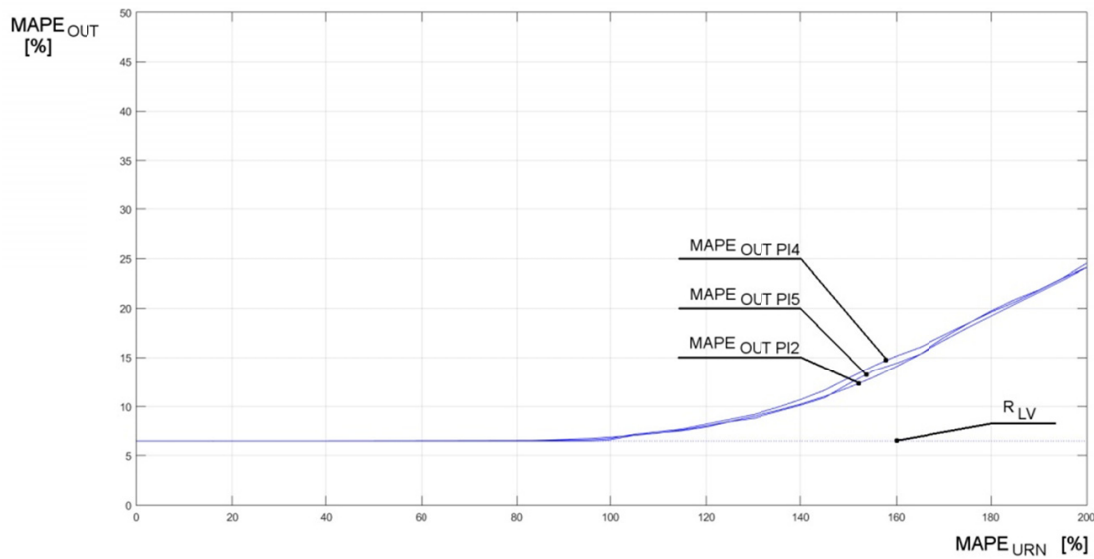

Fig. 10. Characteristics of the output indicators: $M A P E_{\text {OUT PI2 }}, M A P E_{\text {OUT PI4 }}$ and $M A P E_{\text {OUT PI5 }}$ according to $M A P E_{U R N}$ index value for the uniform random number signal placed on the current input of regulator in the track of the speed and torque

The value of interference in the output signal increases with increasing content of additive interference in the input signals of controllers, as in the previous case (Fig. 11). The content of interference in the output signal is low until the $M A P E_{U R N}<90 \%$ (curvature of curve). Increase 


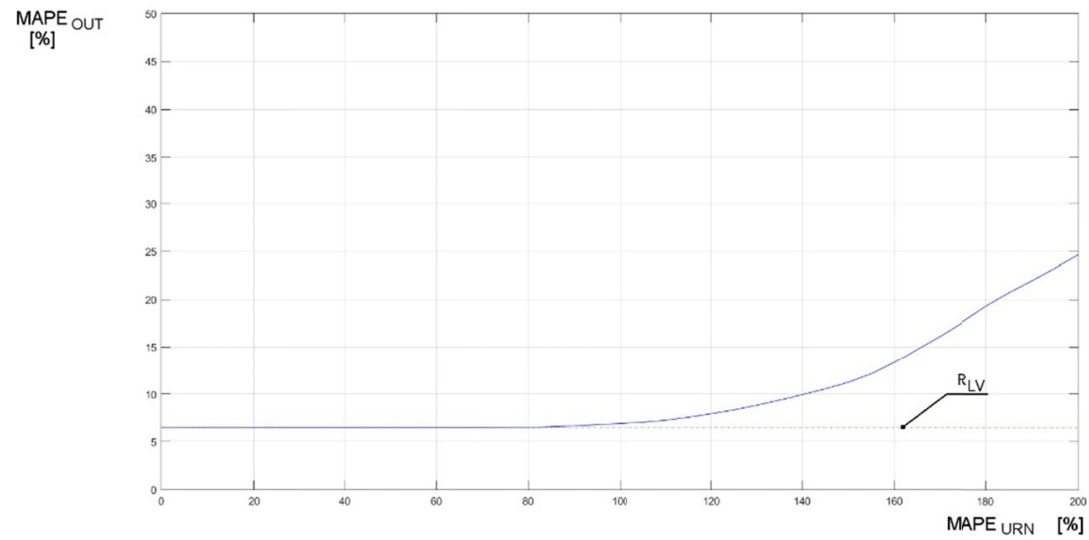

Fig. 11. Characteristics of the output indicators: $M A P E_{O U T}$ for the case, when introduced additive interfering with the input signals of all controllers

in content of the additive signal random number above the $90 \%$ of the input signals dramatically increases the content of interference in the output signal. A disturbing uniform random number signal has less impact on the speed of slip-ring induction motor than previously tested random number interfering signal.

\subsection{The impact of the additive chirp signal in the range of $0.1 \mathrm{~Hz}$ to $10 \mathrm{~Hz}$ on the quality of the regulation}

The additive effect of interfering signals on the input signals of individual controllers separately and all together have been studied.

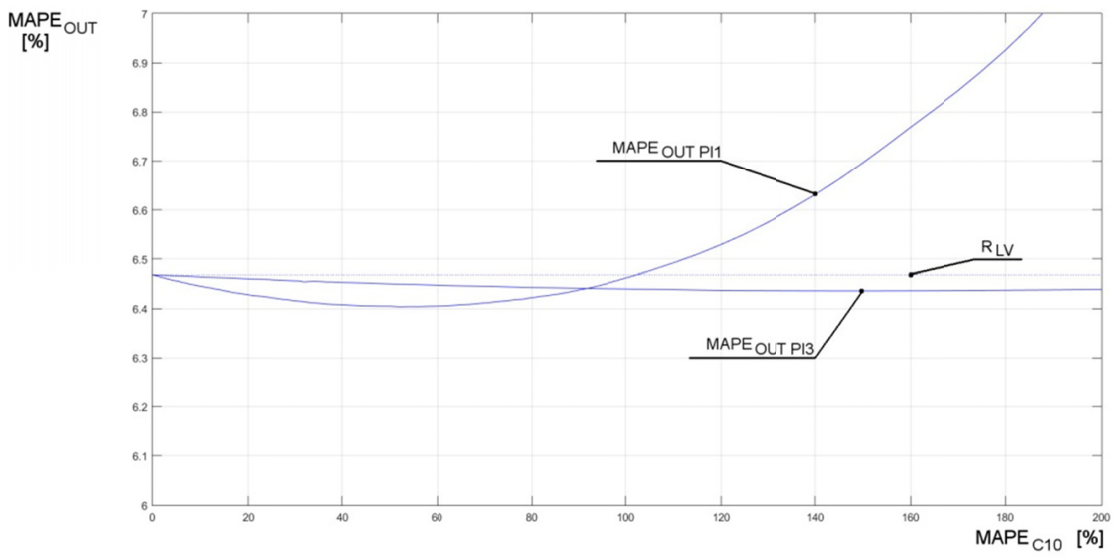

Fig. 12. Characteristics of the output indicators: $M A P E_{O U T} \mathrm{PI} 1$ and $M A P E_{O U T \mathrm{PI}}$ according to the $M A P E_{C 10}$ index value for the chirpsignal in the range of $0.1 \mathrm{~Hz}$ to $10 \mathrm{~Hz}$ placed on the current input of regulator in the track of the magnetic flux 
Effect of additive interference introduced into the input signals of regulators PI1 and PI3 is less than the input signals of regulators PI2, PI4, PI5 (Fig. 13). The impact of additive interference introduced to the input of the flux regulator slightly decreases. The indicator values $M A P E_{O U T \text { PI1 }}$ initially decrease, and after crossing the $M A P E_{C 10}=50 \%$ start to rise. At the point $M A P E_{C 10}=100 \%$ value of the index $M A P E_{O U T \text { PI } 1}$ intersect the reference level value $R_{L V}$. Since there are points where the $M A P E_{O U T \text { PI1 }}<R_{L V}$, and therefore controller parameters PI1 are not optimal, as controller parameters PI3.

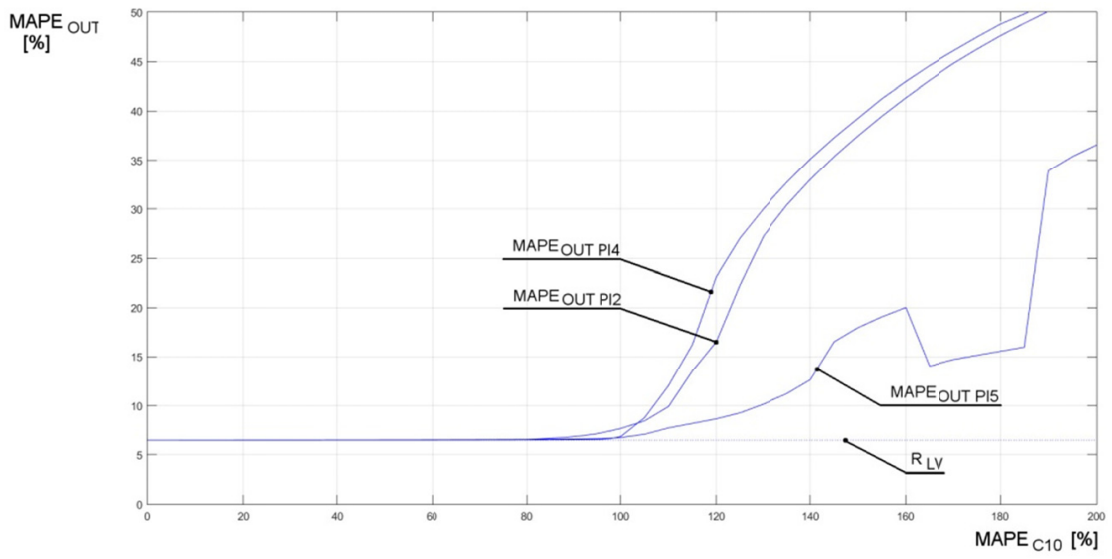

Fig. 13.Characteristics of the output indicators: MAPE $E_{\text {OUT PI2 }}, M A P E_{O U T \text { PI4 }}$ and MAPE $E_{\text {OUT PI5 }}$ according to $M A P E_{C 10}$ index value for the chirp signal in the range of $0.1 \mathrm{~Hz}$ to $10 \mathrm{~Hz}$ placed on the current input of regulator in the track of the speed and torque

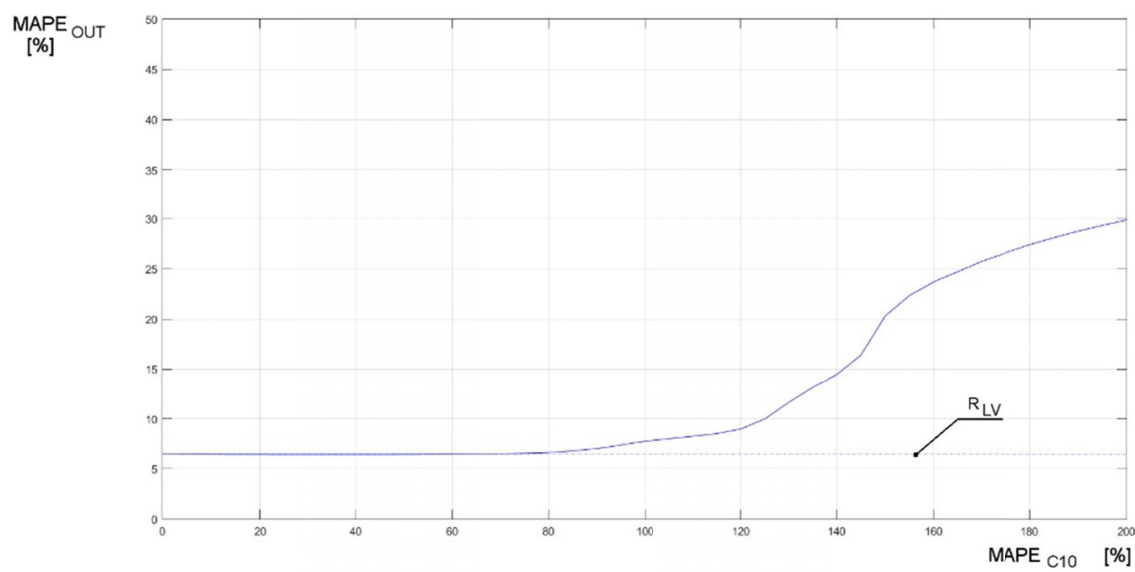

Fig. 14. Characteristics of the output indicators: $M A P E_{\text {OUT }}$ for the case, when introduced additive interfering with the input signals of all controllers 


\subsection{The impact of the additive sine wave signal}

Content of interference in the output signal increases with increasing content of additive interference in the signal input of the regulators. The content of interference in the output signal is low until the $M A P E_{C 10}<80 \%$. The increase of the additive chirpsignal in the range of $0.1 \mathrm{~Hz}$ to $10 \mathrm{~Hz}$ above the $80 \%$ of the input signals dramatically increases with the content of distortion in the output signal. Chirpsignal interfering signal in the range of $0.1 \mathrm{~Hz}$ to $10 \mathrm{~Hz}$, has a much better impact than previously tested signals. The research was carried out also for the same signal but with different parameters. The upper limit is set at $10 \mathrm{~Hz}$ frequency (presented studies and conclusions), $100 \mathrm{~Hz}$ and $1 \mathrm{kHz}$. It was observed that the system is more sensitive to low frequency noise, so in order not to blur the conclusions of this research, we abandoned the presentation of the study for two signals of higher frequency limits.

The influence of the additive disturbing signal of given frequencies (Table 2) and with specified amplitudes (Table 1) was analyzed. The effects of the additive interference signals at the inputs of individual controller separately and all together, in the path of the magnetic flux path and speed have been studied.

The values of interference frequency

\begin{tabular}{|c|c|}
\hline No. & Frequency [Hz] \\
\hline 1. & 1 \\
2. & 2 \\
$\ldots$ & $\ldots$ \\
5. & 5 \\
6. & 10 \\
7. & 15 \\
$\ldots$ & $\ldots$ \\
14. & 50 \\
15. & 60 \\
$\ldots$ & $\ldots$ \\
19. & 100 \\
20. & 150 \\
$\ldots$ & $\ldots$ \\
27. & 500 \\
28. & 1000 \\
$\ldots$ & $\ldots$ \\
36. & 5000 \\
37. & 10000 \\
\hline
\end{tabular}

Sinusoidal signal is characterized by, inter alia, amplitude and frequency. Presented characteristics (Fig. 15-20) are a three-dimensional arrangement, the axis was determined by the frequency of the test interference signal $(f)$ and the content of the disturbing signal in the input signal of the test controller $\left(M A P E_{S W}\right)$. The scale of the frequency axis is a logarithmic scale.

The impact of interfering frequency sinusoidal signal and the value of the indicator $M A P E$ of this signal in the input signal of the controller PI1 (Fig. 15) are shown. The highest values of the indicator $M A P E_{\text {OUT PI1 }}$ are the values at low frequencies in the range of 10-100 $\mathrm{Hz}$. 


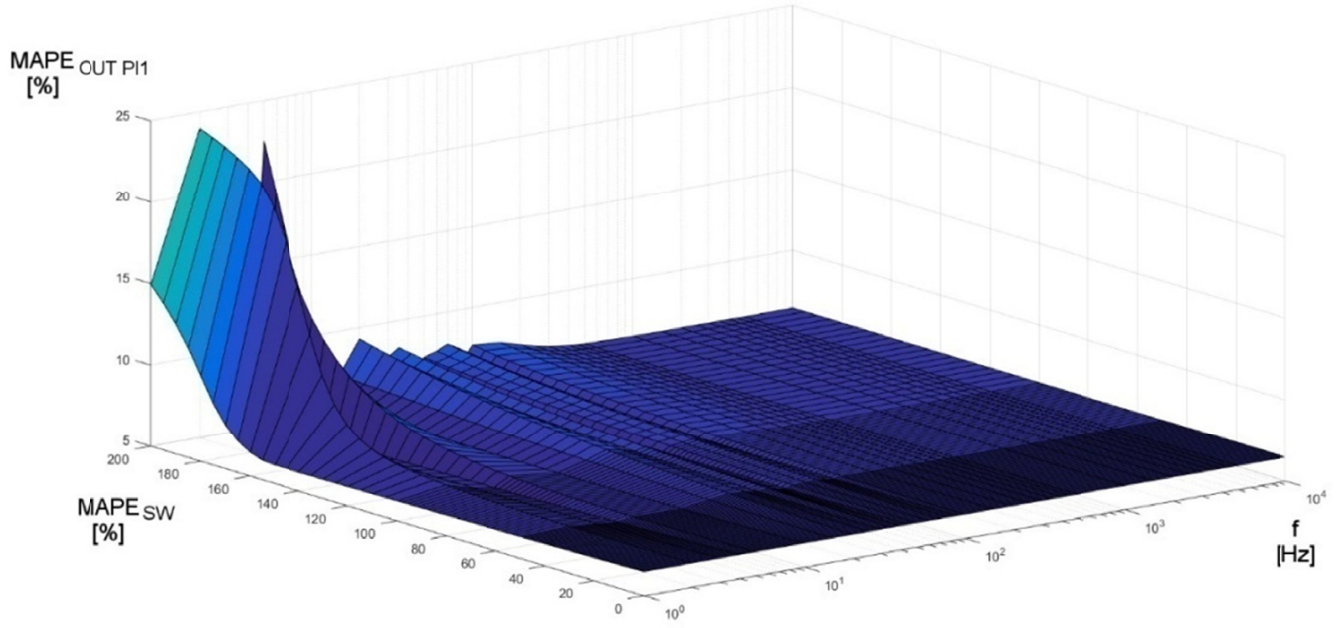

Fig. 15.Characteristics of the output indicator $M A P E_{O U T}$ PI1 according to the $M A P E_{S W}$ index value for the interfering additive signal introduced into the current controller input in the track of the magnetic flux

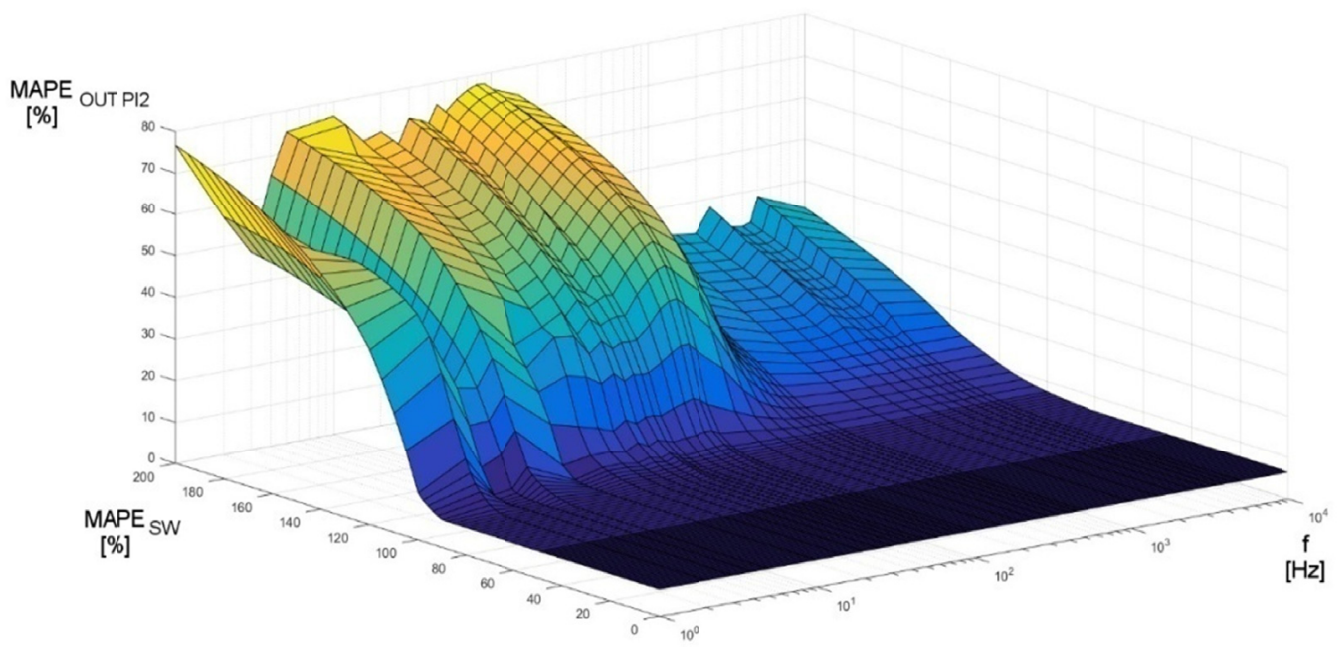

Fig. 16. Characteristics of the output indicator $M A P E_{O U T \text { PI2 }}$ according to the $M A P E_{S W}$ index value for the interfering additive signal introduced into the current controller input in the track of the speed

The impact of interfering frequency sinusoidal signal and the value of the indicator $M A P E$ of this signal in the input signal of the controller PI2 (Fig. 16) are shown. The highest values of the index $M A P E_{O U T}$ PI2 are the values for the low frequency range up to $100 \mathrm{~Hz}$. The significant values of interference in the output signal $M A P E_{O U T \text { PI } 2}$ can be noticed for the input values $M A P E_{S W}>60 \%$.

The impact of interfering frequency sinusoidal signal and the value of the indicator $M A P E$ of this signal in the input signal of the controller PI3 (Fig. 17) are shown. The parameters of 


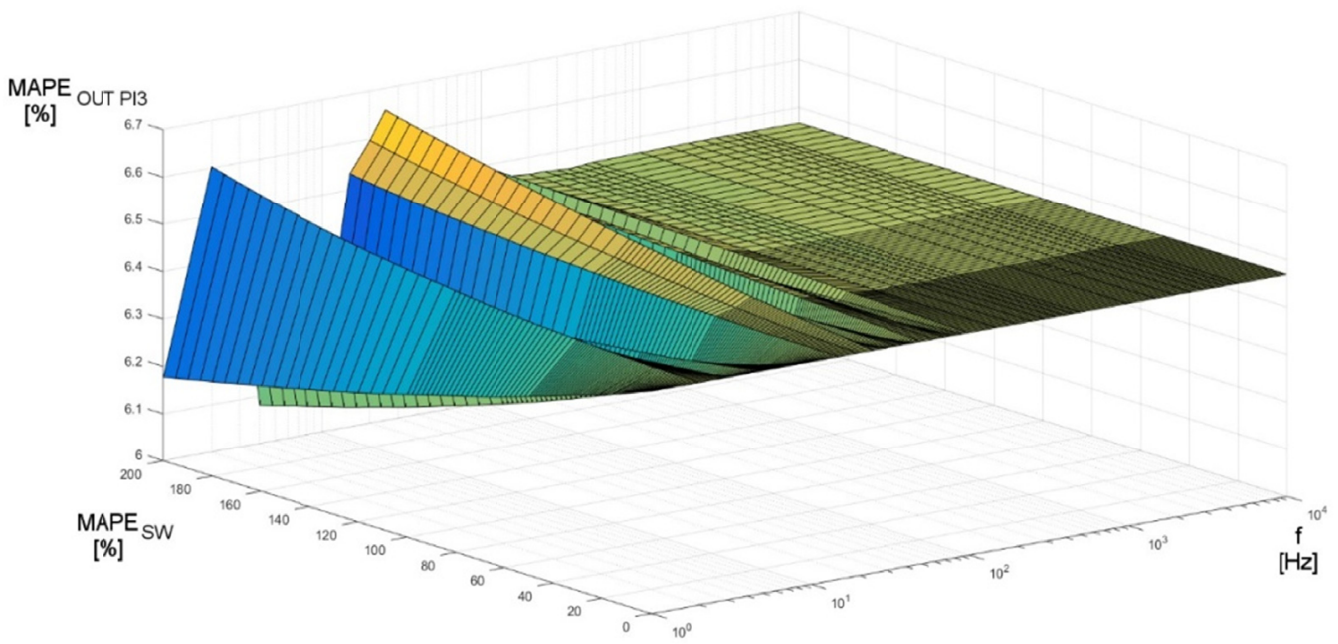

Fig. 17. Characteristics of the output indicator $M A P E_{O U T} \mathrm{PI} 3$ according to the $M A P E_{S W}$ index value for the interfering additive signal introduced into the current controller input in the track of the magnetic flux

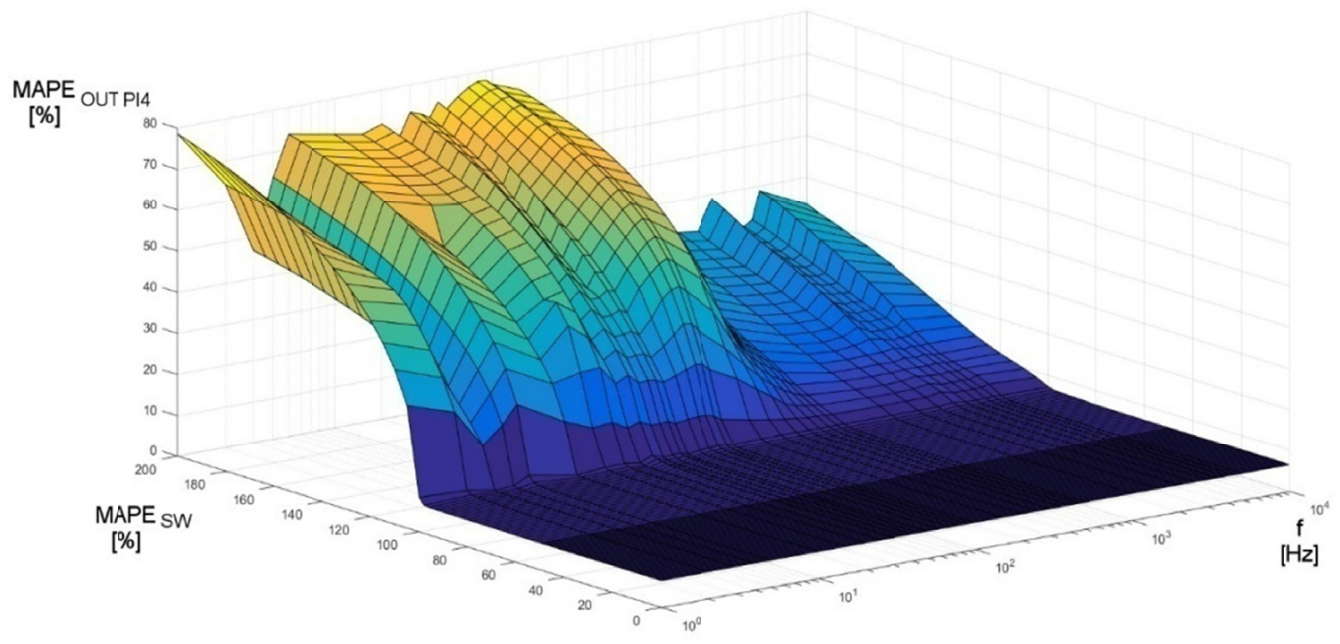

Fig. 18. Characteristics of the output indicator $M A P E_{O U T} \mathrm{PI} 4$ according to the $M A P E_{S W}$ index value for the interfering additive signal introduced into the current controller input in the track of the torque

this regulator are not optimal. The indicator values $M A P E_{\text {OUT PI3 }}$ vary around the value of the reference level for the whole research area. Interference placed on the input of regulator PI3 has a negligible effect on the output signal.

The impact of interfering frequency sinusoidal signal and the value of the indicator $M A P E$ of this signal in the input signal of the controller PI4 (Fig. 18) are shown. The highest values of the indicator $M A P E_{O U T}$ PI 4 are the values for the low frequencies up to $100 \mathrm{~Hz}$, as in the case of 
value of the index $M A P E_{\text {OUT PI2. }}$. Significant values of the contents of interference in the output signal MAPE $E_{O U T \text { PI4 }}$ can be noticed for the input values $M A P E_{S W}>70 \%$.

The impact of interfering frequency sinusoidal signal and the value of the indicator $M A P E$ of this signal in the input signal of the controller PI5 (Fig. 19) are shown. The conclusions are as for the case when the introduced additive interfering signals at the input of regulator PI4.

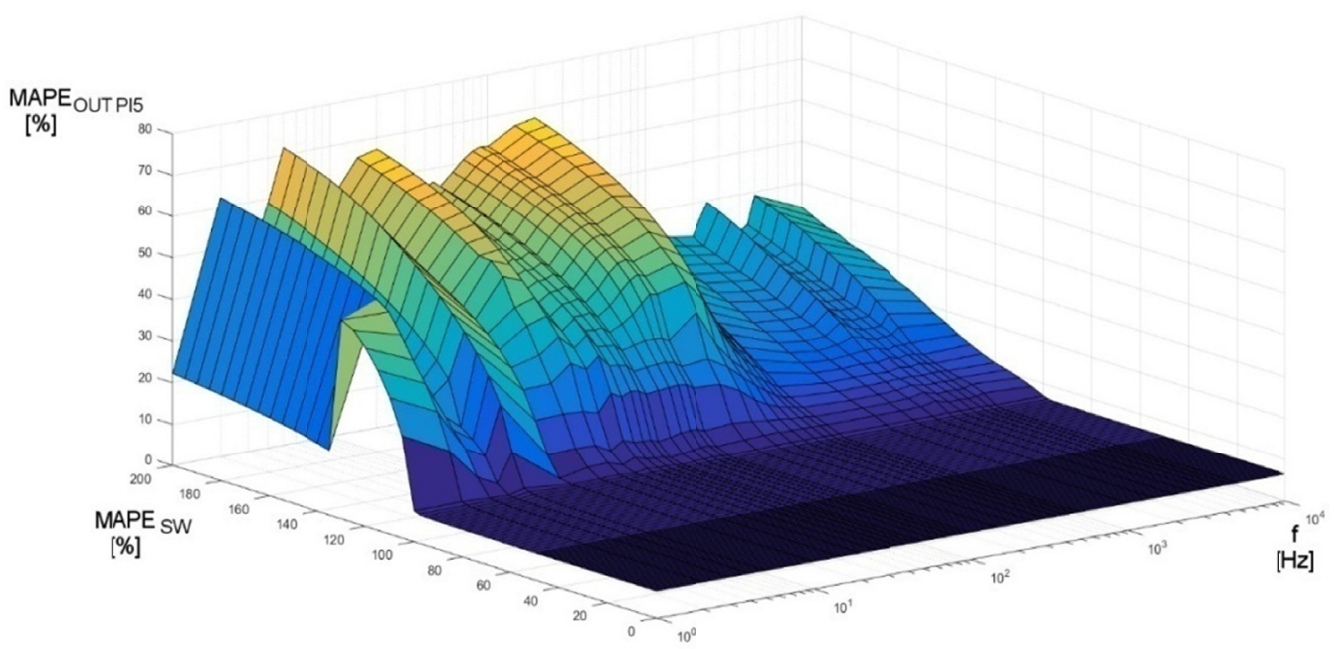

Fig. 19.Characteristics of the output indicator $M A P E_{O U T}$ PI5 according to the $M A P E_{S W}$ index value for the interfering additive signal introduced into the current controller input in the track of the speed

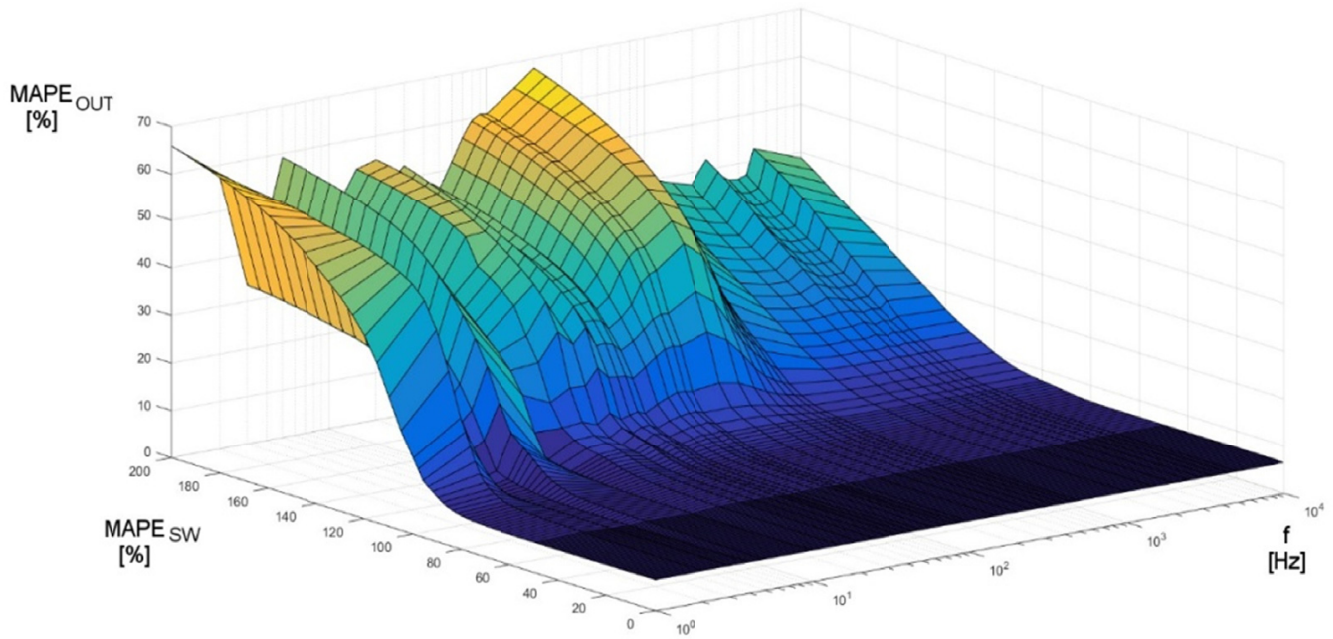

Fig. 20.Characteristics of the output indicator $M A P E_{\text {OUT PI1-OUT15 }}$ according to the $M A P E_{S W}$ index value for the interfering additive signal introduced into the current controller input in the track of the magnetic flux and the speed and torque 
The impact of interfering frequency sinusoidal signal and the value of the indicator MAPE of this signal of the input signal of all controllers PI simultaneously (Fig. 20). Lower frequencies interfering signals have a greater impact on the level of interference in the output signal. Moreover, the level of interfering signals to values of $M A P E_{S W}<60 \%$ was an acceptable level. Above this value in the course of the rotational speed, which realized tested control system, can be seen significant disruption affecting negatively, especially mechanically on the slip-ring induction motor and the engaged with it other devices.

\section{Summary}

As can be seen from the research, the content of disruption in output $M A P E_{O U T}$ signals grew with the increase of interference in the input signals of regulators.

The level of the minimum content of disruption in the analyzed example was $M A P E_{O U T}$ $=6.47 \%$. In some cases (interference signals placed on the electromagnetic torque controller input and the input current controller in the lines of rotational speed characterized by lower values. This is due to non-optimal settings of PI controllers of the test control system, which is caused by the used method of parametric optimization.

The tested control system has two independent (due to the use of suitable transformation systems) lanes of adjustment. Introduced interference signals in the track of rotational speed regulator is characterized by the significantly lower effect on the output than the corresponding interfering signals placed on the input controls located on the track of the magnetic flux.

Even small interfering signals can cause adverse reaction of the control system and resulting with this change to a graph of rotational speed of the controlled motor. Impulses of rotational speed adversely affect the durability of the shaft of power supply and the unit which supplies the engine may occur. The study shows that even relatively large values of distortion of the input signals of regulators range up to $50 \%$ does not have a negative impact on the course of values of rotational speed of tested control system.

The field oriented control system with slip-ring induction motor with the identified evolutionally controller parameters proved to be resistant to interference.

\section{References}

Gumuła S., Pytel K., Piaskowska-Silarska M., 2014a. Polemical Remarks to the Claim that Carbon Dioxide Strengthens the Greenhouse Effect in the Atmosphere. Pol. J. Environ. Stud. 23, 6, 2321-2325.

Gumuła S., Pytel K., Piaskowska-Silarska M., 2014b. Environmental and Economic Benefits of Using Kinetic Wind Energy to Generate Electricity. Pol. J. Environ. Stud. 23, 6, 2315-2320.

Hudy W., 2013. Analysis of parametric optimization of field-oriented control of 3-phase induction motor with using evolutionary algorithm. Transactions of the VŠB - Technical University of Ostrava; Mechanical Series, 59, 2, 1959.

Hudy W., Noga H., 2014. Influence of various types of interference of entry signals'of regulators type pi in field oriented control system with induction motor on initial rotational speed. ICEMEE 2014, Guangzhou, China, 25-26 October,

Leonard W., 1985. Control of Electrical Drives. Springer Verlag, Berlin, Germany. 
Orłowska-Kowalska T., 2003. Control systems of the induction motors without sensors. Oficyna Wydawnicza PW, Wrocław, Polska.

Pytel K., Jaracz K., 2012. Analiza możliwości wykorzystania wybranych hybrydowych układów pozyskiwania energii ze źródel odnawialnych. Poznan University of Technology Academic Journals. Electrical Engineering, 70, 173-180.

Pytel K., Jaracz K., Gumula S., 2012. An impact of chosen construction parameter and operating conditions on the quality of wind turbine energy generation. ICCC 2012, High Tatras, Slovakia, 28-31 May, 592-595. 